\title{
Penerapan Aplikasi Up-Event pada Tata Kelola Kegiatan Multi Vendor
}

\author{
Usman Nurhasan ${ }^{1}$, Mustika Mentari ${ }^{2}$, Kirana Widi Hartati ${ }^{3}$, Noviana Ningtyas ${ }^{4}$ \\ 1,2,3,4 Teknologi Informasi, Politeknik Negeri Malang \\ E-mail: ${ }^{* 1}$ usmannurhasan@polinema.ac.id, \\ 2.must.mentari@polinema.ac.id, ${ }^{3}$ kiranawidihartati@gmail.com, ${ }^{4}$ novianan76@gmail.com
}

\begin{abstract}
Abstrak- Event organizer dapat didefinisikan sebagai pengorganisasian sebuah kegiatan yang dikelola secara profesional, sistematis, efisien dan efektif. Kegiatannya meliputi konsep (perencanaan), pelaksanaan hingga pengawasan. Saat ini sistem penyebaran informasi event dilakukan dengan cara mempromosikan eventmelalui website, social media dan juga masih banyak event organizer yang melakukan penjualan tiket event secara offline dengan membuka stand di event lain maupun di daerah tertentu. Pendistribusian tiket dengan cara ini menimbulkan beberapa masalah yaitu terjadinya antrian panjang yang akan menghabiskan banyak waktu dan adanya biaya tambahan untuk mendirikan stand tersebut. Peluang untuk penyebaran informasi event dan penjualan tiket secara online mulai dilirik oleh event organizer sebagai lahan yang menjanjikan karena menyediakan informasi yang akurat serta menghemat waktu dan juga biaya saat promosi. Dari permasalahan tersebut, kami merancang sebuah aplikasi "Up-Event" sistem ini berguna untuk membantu event organizer dalam penjualan tiket event. Sistem ini selain berbasis website juga berbasis android. Di sistem ini dilengkapi fitur absensi peserta event menggunakan teknologi QR Code. Selain untuk mengurangi penggunaan kertas yang terlalu banyak dan antrian yang panjang saat absensi peserta, QR Code juga menjamin keamanan event karena dapat diketahui keaslian tiket yang digunakan sebagai syarat masuk peserta kedalam tempat acara. Hasil yang didapatkan rata - rata skor 80 SUS 73,75 termasuk pada kategori acceptable, hal ini menunjukkan bahwa aplikasi yang dikembangkan dapat diterima oleh pengguna akhir dengan baik ditinjau dari aspek usability.
\end{abstract}

Kata Kunci- Event Organizer, Manajemen Event, QR Code, Tiket

Abstract - An event organizer can be defined as organizing an activity that is managed professionally, systematically, efficiently and effectively. Its activities include concepts (planning), implementation and supervision. Currently the event information dissemination system is carried out by promoting events through the website, social media and also many event organizers who sell event tickets offline by opening stands at other events and in certain areas. Distribution of tickets in this way raises several problems, namely the occurrence of long queues that will spend a lot of time and the additional costs of establishing the stand. Opportunities for the dissemination of event information and online ticket sales began to be glimpsed by the event organizer as a promising land because it provides accurate information and saves time and costs while promoting. From these problems, we designed an application "Up-Event" system that is useful to assist event organizers in selling ticket events. This system besides being based on website is also based on Android. In this system, the attendance feature of the event participant uses $Q R$ Code technology. In addition to reducing the use of too much paper and long queues during attendance, $Q R$ Code also guarantees the security of the event because the authenticity of tickets is used as a condition for entry into the event. The results obtained an average score of 80 SUS 73.75 included in the category of acceptable, this shows that applications developed can be accepted by end users well in terms of usability aspects.

Keywords - Event Organizer, Event Management, QR Code, Ticket 


\section{PENDAHULUAN}

Event organizer dapat didefinisikan sebagai pengorganisasian sebuah kegiatan yang dikelola secara professional, sistematis, efisien dan efektif. Kegiatannya meliputi konsep (perencanaan) sampai dengan pelaksanaan hingga pengawasan. Dalam event organizer, semua orang harus bekerja keras dengan visi yang sama untuk menghasilkan kegiatan yang sesuai dengan harapan. Sangatlah diperlukan kekompakan pada setiap orang yang terlibat di dalam tim. Dalam menyelenggarakan sebuah event, event organizer harus melakukan persiapan dengan teliti dan matang. Persiapan event mulai dari penentuan venue atau tempat acara, dekorasi tempat acara, konsumsi peserta, keamanan pelaksanaan acara, pendistribusian tiket hingga penyebaran informasi mengenai event yang akan diselenggarakan [1].

Saat ini sistem penyebaran informasi dilakukan sendiri oleh event organizer. Dengan cara mempromosikan event melalui website dan juga media social [2]. Dalam proses pendistribusian tiket event masih banyak event organizer yang mekakukan penjualan tiket event secara offline dengan cara membuka stand-stand di sebuah event lain maupun di daerah tertentu. Pendistribusian tiket dengan cara ini menimbulkan beberapa masalah yaitu terjadinya antrian panjang pada saat pembelian tiket yang akan menghabiskan banyak waktu dan belum lagi ketika adanya biaya tambahan untuk mendirikan stand-stand tersebut[3]. Peluang untuk penyebaran informasi event dan penjualan tiket secara online mulai dilirik oleh banyak event organizer sebagai lahan yang menjanjikan. Karena dengan adanya penyebaran informasi penjualan tiket secara online berarti setiap proses transaksi akan divalidasi secara personal. Selain menyediakan informasi yang akurat juga dapat menghemat waktu dan biaya saat promosi [4].

Di negara maju penggunaan informasi juga sangat cepat, terlebih seperti negara Korea Selatan. Rata-rata di Korea Selatan sudah menggunakan transaksi dengan menggunakan $Q R$ Code tujuannya adalah untuk mempercepat layanan, karena di era modern sekarang hampir semua orang memiliki smartphone, dan bahkan sudah di dukung menggunakan QR Code Scan agar semua orang bisa mengakses sekaligus membaca $Q R$ Code Scan tersebut.

Dari permasalahan tersebut, kami merancang sebuah aplikasi yaitu "Up-Event" Sistem ini berguna untuk membantu event organizer dalam penjualan tiket event, seperti mengelola event yang akan berlangsung, mengelola pendaftaran peserta dan lainnya. Sistem ini selain berbasis website juga berbasis android karena saat ini android sudah banyak digunakan di kalangan masyarakat sehingga pengguna menjadi lebih mudah untuk melakukan akses dan melihat event-event yang akan berlangsung beserta detail informasinya [5]. Di sistem ini di lengkapi fitur untuk check kedatangan peserta event menggunakan teknologi $Q R$ Code. Sebelum peserta event memasuki tempat acara, peserta diwajibkan untuk menunjukkan tiket kepada panitia event organizer, dan panitia event organizer akan melakukan pindai $Q R$ Code yang terdapat di tiket[6]. Selain untuk mengurangi penggunaan kertas yang terlalu banyak dan antrian yang panjang ketika kegiatan check, $Q R$ Code juga menjamin keamanan event karena dapat diketahui keaslian tiket yang digunakan sebagai syarat masuk tempat acara.

\section{METODE PENELITIAN}

\subsection{Metodologi}

Metode yang digunakan dalam pengembangan aplikasi Up-Event ini adalah metode waterfall dan untuk memperjelas akan ditampilkan pada gambar 1. Metode waterfall adalah model yang banyak digunakan untuk pengembangan perangkat lunak. Model berkembang secara sistematis dari satu tahap ke tahap lain dalam mode seperti air terjun. Dalam metode waterfall yang akan diterapkan memiliki lima tahap, yaitu analisis kebutuhan, desain sistem, implementasi, pengujian, dan maintenance [6]. 


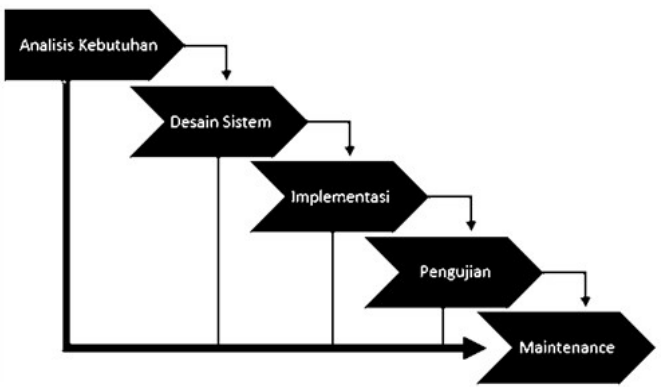

Gambar 1 Metode Waterfall

\section{a. Analisis Kebutuhan}

Tahap awal adalah analisa kebutuhan, tahapan ini diawali dengan mencari kebutuhan-kebutuhan dari semua elemen sistem dan akan dialokasikan ke dalam pembentukan perangkat/sistem. Spesifikasi kebutuhan sistem terdiri dari spesifikasi kebutuhan fungsional dan kebutuhan nonfungsional.

\section{Kebutuhan Fungsional}

Kebutuhan fungsional merupakankebutuhan yang berisi proses-proses apa saja yang nantinya dilakukan oleh sistem. Berikut adalah kebutuhan fungsional dari aplikasi ini :

1 Admin

- Melihat list akun user/pengguna

- Menghapus akun user/pengguna

- Melihat listevent

- Menghapus event

- Melihat listevent organizer

- Menghapus event organizer

- Melihat list pemesanan tiket event

- Melihat list peserta event

2 Event organizer

- Mengelola Event

- Mengelola peserta Event

- Melihat listpeserta event

- Melihatlist hadir peserta

- Mengkonfirmasi pembayaran tiket

- Men-scanQR Code tiket

3 User

- Melihat event apa saja yang akan berlangsung

- Mendaftar ke event

- Konfirmasi pembayaran tiket

- Mendapatkan tiket masuk event

- Melihat riwayat pemesanan tiket

\section{Kebutuhan Non-fungsional}

Kebutuhan non-fungsional merupakan batasan layanan atau fungsi yang ditawarkan sistem.Berikut adalah kebutuhan non-fungsional dari aplikasi ini:

- Sistem ini menggunkan dua platform yaitu android dan website.

- Pada aplikasi android dapat diakses oleh peserta dan event organizer.

- Pada website dapat diakses oleh admin.

- Aplikasi ini digunakan secara online.

- Terdapat register akun untuk event organizer yang ingin mendaftarkan event-nya. 
- Terdapat $Q R$ Code di tiket untuk keamanan event serta memudahkan event organizer saat absensi berlangsung.

- Pada event organizer terdapat fitur untuk scanQR code tiket masuk.

\section{b. Desain Sistem}

Tahapan ini mencakup pada pembuatan proses bisnis system, desain database dan user interface. Desain system disesuiakan dengan kebutuhan-kebutuhan yang harus dipenuhi dari tahapan sebelumnya. Pada aplikasi ini, dibuat perancangan system dalam bentuk UML. Hal ini bertujuan untuk mempermudah deploy aplikasi ketika akan dterapkan dengan konsep object oriented [7].

\section{c. Implementasi}

Sistem nantinya akan diterapkan pada pelaku event baik pihak manajerial atau user. Unjuk kerja dari aplikasi akan diuji coba dengan menggunakan konsep blackbox. Hal ini bertujuan untuk mendapatkan kesalahan yang terdapat dalam sistem[7]. Dari kesalahn ini kemudian aplikasi dapat dikembangkan menjadi lebih baik.

\section{d. Pengujian}

Pada tahapan ini dilakukan pengujian system yang telah dibangun. Pengujian dilakukan pada dua hal, unjuk kerja system dan respon dari user. Hal ini dilakukan untuk dapat menilai sejauh mana aplikasi dapat mengakomodir kebutuhan user. Harapannya adalah ketika dilakukan pengembangan dapat didasari oleh kebutuhan-kebutuhan user.

\section{e. Maintenance}

Tahapan akhir dari pembuatan aplikasi adalah melakukan evaluasi terhadap permodelan yang telah dilakukan sebelum diimplementasikan pada objek penelitian. Pada tahap ini, akan dilakukan evaluasi dengan cara membangun purwarupa yang sesuai dengan keadaan di lapangan sehingga dapat diketahui kesalahan-kesalahan apa saja yang terjadi dan dapat dilakukan perbaikan secepatnya.

\subsection{Perancangan Sistem}

Tahap penerjemah dari keperluan atau data yang dianalisis ke dalam bentuk yang mudah dimengerti oleh pemakai (user). Proses ini berfokus pada struktur data, arsitektur perangkat lunak, representasi interface, dan detail (algoritma) prosedural. Berikut adalah perancangan sistemnya, yaitu:

\subsubsection{Proses Bisnis Sistem}

Arsitektur sistem Up-Event yang akan dibangun merupakan interaksi antara event organizer, user dan admin. Berikut merupakan gambar desain sistem Up-Event. 


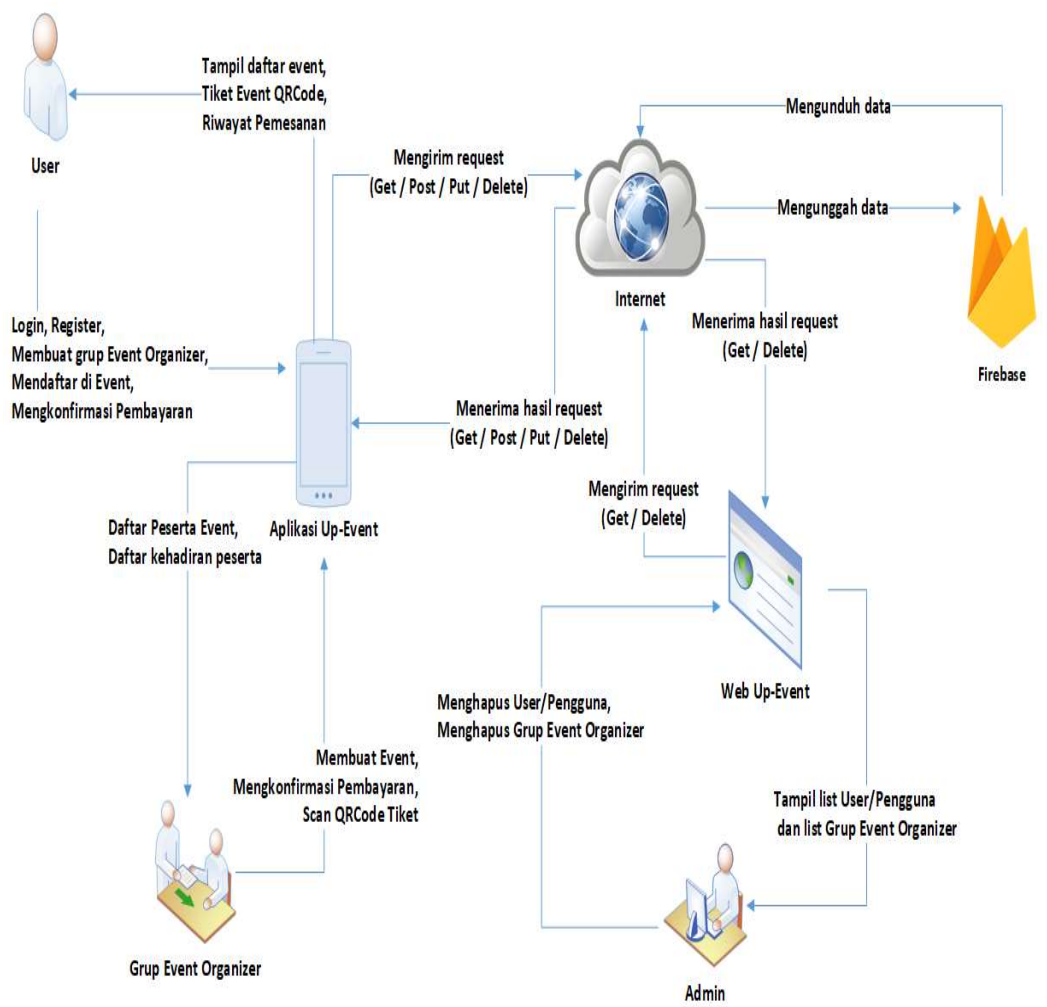

Gambar 2 Proses Bisnis Sistem

Sistem Up-Event menggunakan dua platform yaitu Android dan website. Aplikasi UpEvent pada Android digunakan oleh event organizer dan user, sedangkan untuk website Up-Event hanya dapat digunakan oleh admin. Admin dapat mengola data event, mengelola peserta event, mengelola event organizer dan mengelola daftar bank. User dapat melakukan pesan tiket event, konfirmasi pembayaran tiket dan melihat riwayat pemesanan tiket. Event organizer dapat mengelola anggota, mengelola event, mengelola peserta event, mengkonfirmasi pembayaran tiket dan dapat melakukan scan $Q R$ Code tiket saat absensi peserta.

Sistem Up-Event ini dalam menjalankannya membutuhkan koneksi internet. Setiap user, event organizer dan admin melakukan post, get, update dan delete, sistem akan selalu melakukan request keFirebase melalui internet. Sebelum masuk ke aplikasi user harus mempunyai akun terlebih dahulu. User melakukan registrasi akun Up-Event melalui aplikasi Up-Event di android. Jika user sudah mempunyai akun Up-Event user dapat langsung login ke aplikasi. Di aplikasi ini user dapat membuat grup event organizer-nya sendiri dan membuat event-nya di dalam grup tersebut. Selain membuat grup event organizer, user juga dapat melihat daftar event yang akan berlangsung dari grup event organizer lainnya dan mendaftar ke event tersebut. Jika user ingin mengikuti event maka user dapat langsung memesan tiket event tersebut, setelah selesai melakukan pembayaran user harus mengisi konfirmasi pembayaran untuk mendapatkan tiket masuk. Pada konfirmasi pembayaran user menginputkan bukti pembayaran. Event organizerakan mendapatkan list peserta event dan event organizer dapat mengkonfirmasi pembayaran yang dilakukan masing-masing peserta event. Jika event organizer telah mengkonfirmasi pembayaran tiket, userakan mendapat tiket yang terdapat $Q R$ Code yang akan dikirim melalui aplikasi. User datang ke event dengan membawa tiket tersebut dan menunjukannya ke event organizer untuk di scan. Lalu data $Q R$ Code yang di scanakan tersimpan di database untuk daftar kehadiran peserta event [8]. Untuk menangani event yang sudah kadaluarsa atau event yang kuotanya sudah habis sistem akan secara otomatis men-non active-kan event tersebutsehingga user tidak dapat memilih event tersebut. 


\subsubsection{Physsical Data Model}

Physical data model (PDM) yaitu model yang menggunakan sejumlah tabel untuk menggambarkan data serta hubungan antar data-data yang saling berkaitan. Setiap tabel mempunyai sejumlah kolom dimana setiap kolom memiliki nama yang unik. Pada aplikasi Up-Event akan digunakan setidaknya delapan table yang saling terkait. Table-tabel tersebut akan terhubung ke masing-masing actor bergantung dengan proses yang dikehendaki oleh actor. Berikut merupakan gambar dari physical data model aplikasi Up-Event.

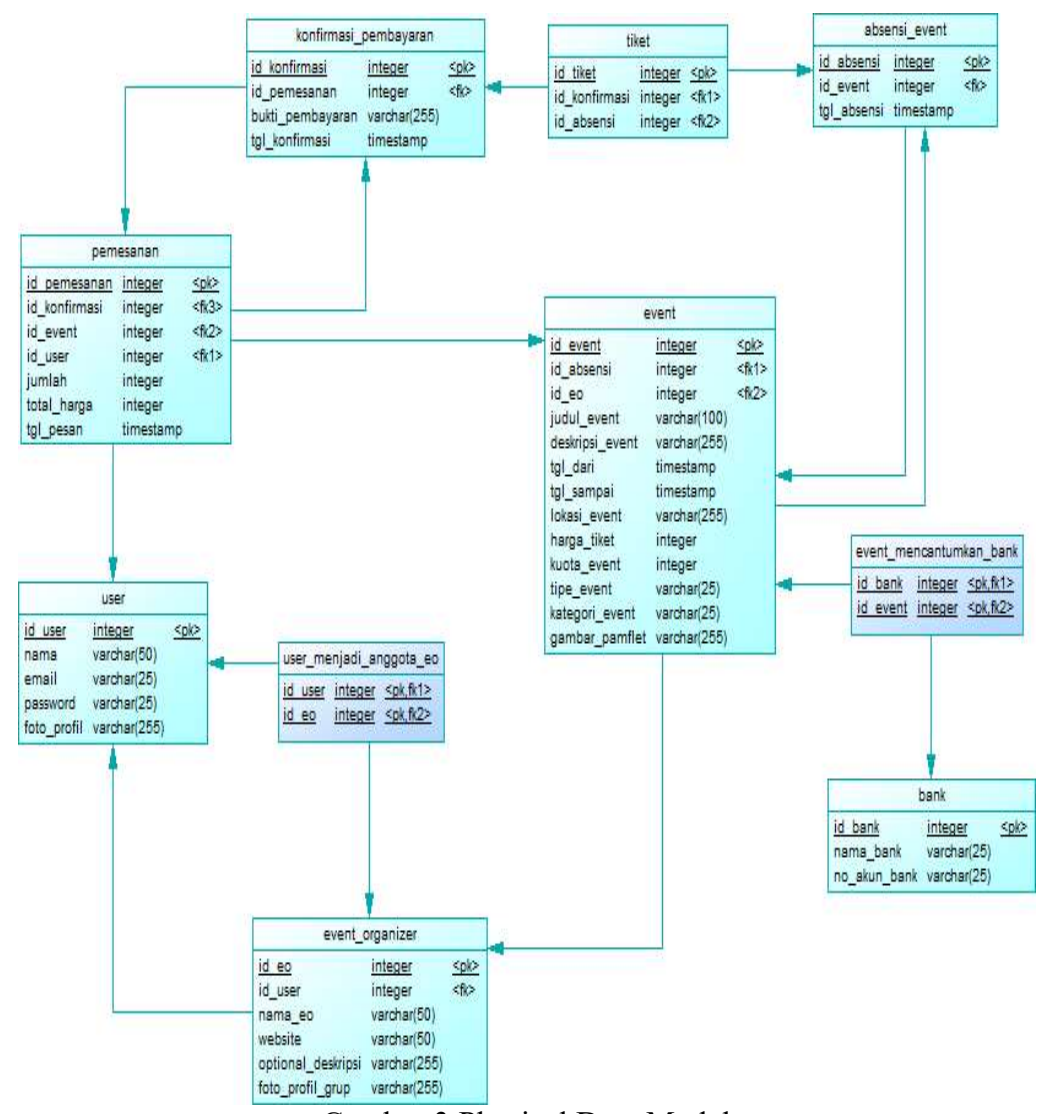

Gambar 3 Physical Data Model

\subsubsection{Unified Modeling Language (UML)}

\section{a. Use Case Diagram}

Use Case diagram adalah gambaran graphical dari beberapa atau semua actor, use case, dan interaksi diantaranya yang memperkenalkan suatu sistem. Pada system Up_Event akan dibuat menjadi tiga actor yang memiliki peran masing-masing dalam memanajemen system. Actor tesebut adalah user/peserta, Event Organizer, dan Admin. Untuk lebih memperjelas, gambar berikut merupakan use case diagram dari aplikasi Up-Event. 


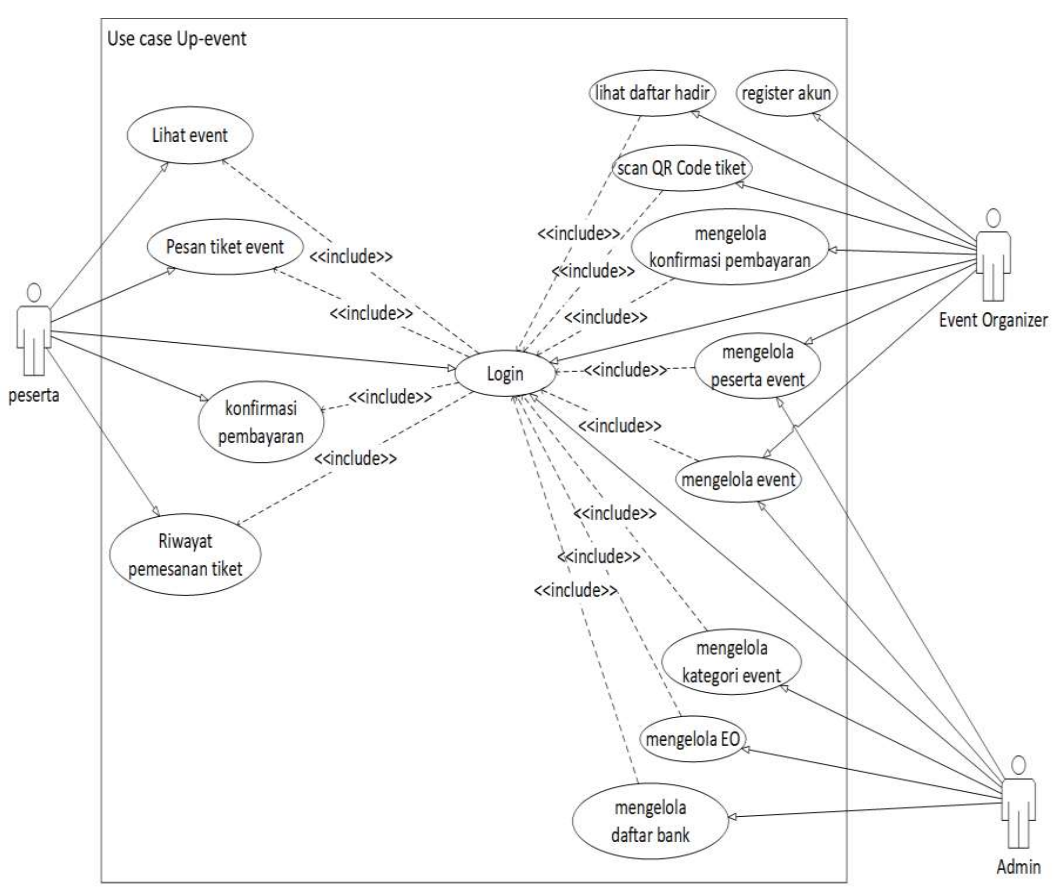

Gambar 4 Use Case Diagram

b. Activity Diagram

Aktifitas yang terjadi pada setiap proses yang terjadi didalam system akan ditampilkan dalam activity diagram. Berikut merupakan activity diagram dari aplikasi Up-Event.

\section{Pesan Tiket Event dan Konfirmasi Pembayaran}

Pesan tiket ini digunakan pengguna untuk memesan tiket event yang ingin diikutinya. Dimulai dari melihat daftar event-event, memilih salah satu event yang ada, dan daftar ke event. Selanjutnya ketika sudah memesan tiket maka akan tampil cara pembayarannya. Konfirmasi pembayaran ini digunakan pengguna jika akan mengkonfirmasi pembayaran yang telah dilakukan untuk membeli tiket. Konfirmasi pembayaran membutuhkan bukti pembayaran. Activity diagram untuk pesan tiket dan konfirmasi pembayaran akan ditunjukkan pada gambar.

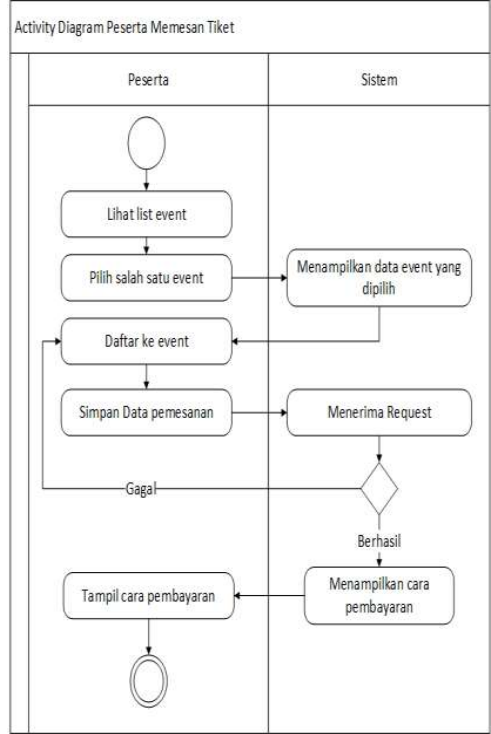

Gambar 5 Activity Pesan Tiket

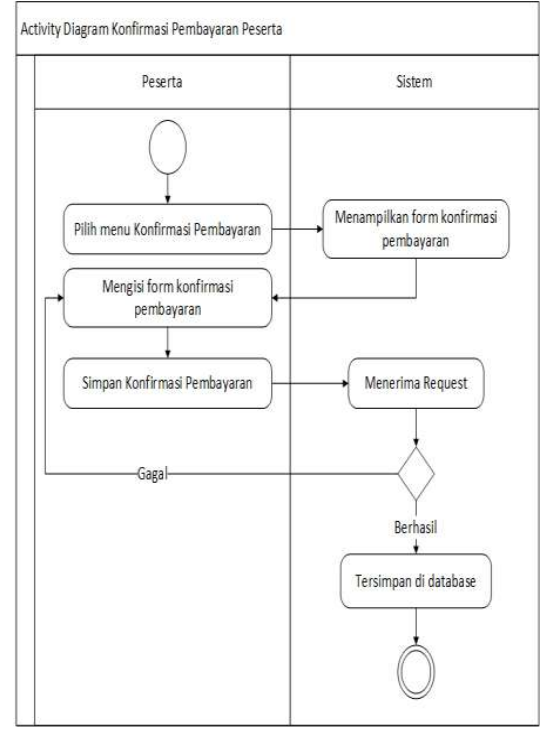

Gambar 6 Activity Konfirmasi Pembayaran 


\section{Mengelola event}

Mengelola event digunakan oleh event organizer untuk mengelola event mulai dari create, update dan delete event. Pada halaman mengelola event melibatkan event organizer dan sistem. Proses inti selanjutnya adalah proses pengelolaan konfirmasi pembayaran. Mengelola konfirmasi pembayaran ini dilakukan oleh event organizer untuk mengelola konfirmasi pembayaran peserta event [9]. Sepertimenerima atau menolak konfirmasi pembayaran yang telah dikirim oleh peserta. Activity diagram untuk mengelola event adalah sebagai berikut.

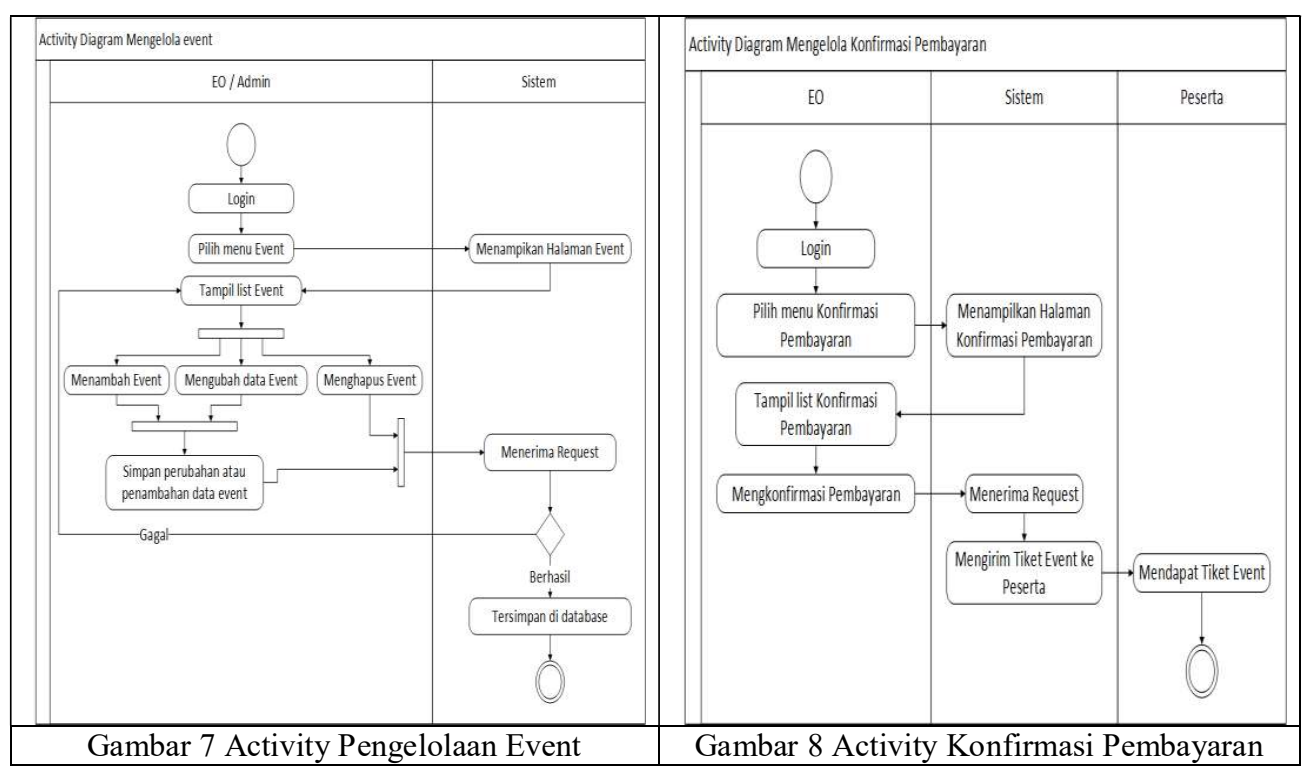

\section{HASIL DAN PEMBAHASAN}

\subsection{Antarmuka}

a. Antarmuka halaman user pada admin website Up-Event.

Pada halaman user pada admin website Up-Event ini berisi tentang user atau pengguna yang sudah mendaftar pada aplikasi. Antarmuka ini memiliki fungsi yang sama pada aplikasi Up-Event platform mobile. Pada halama ini user dapat melakukan manajemen pemilihan eventa yang akan diikuti.

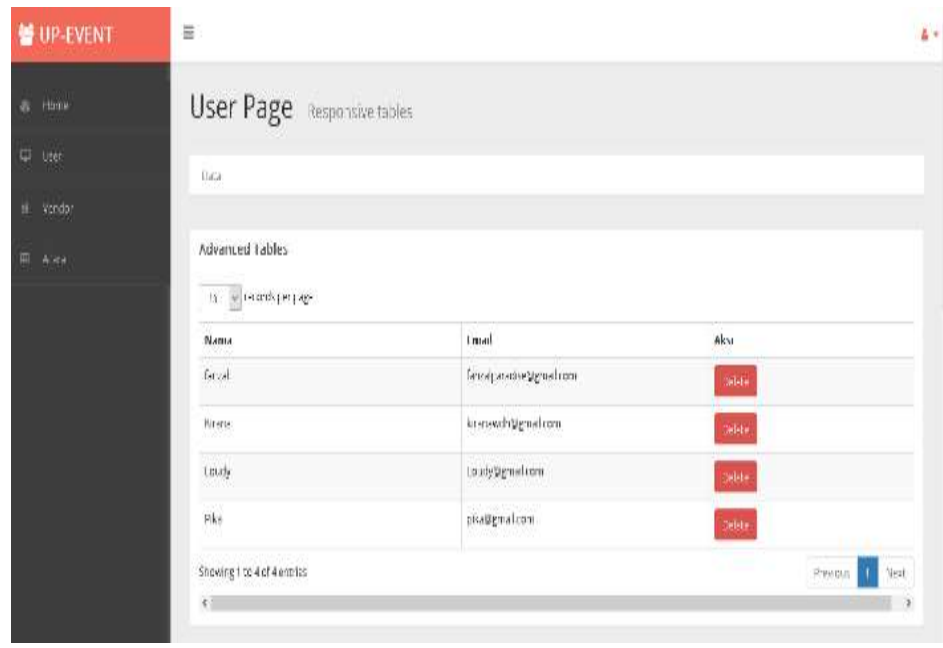

Gambar 9 Antarmuka Halaman User 
b. Antarmuka halaman vendor

Pada halaman ini berisi data event organizer yang telah membuat grup event organizer pada aplikasi android. Berikut antarmuka dari halaman vendor

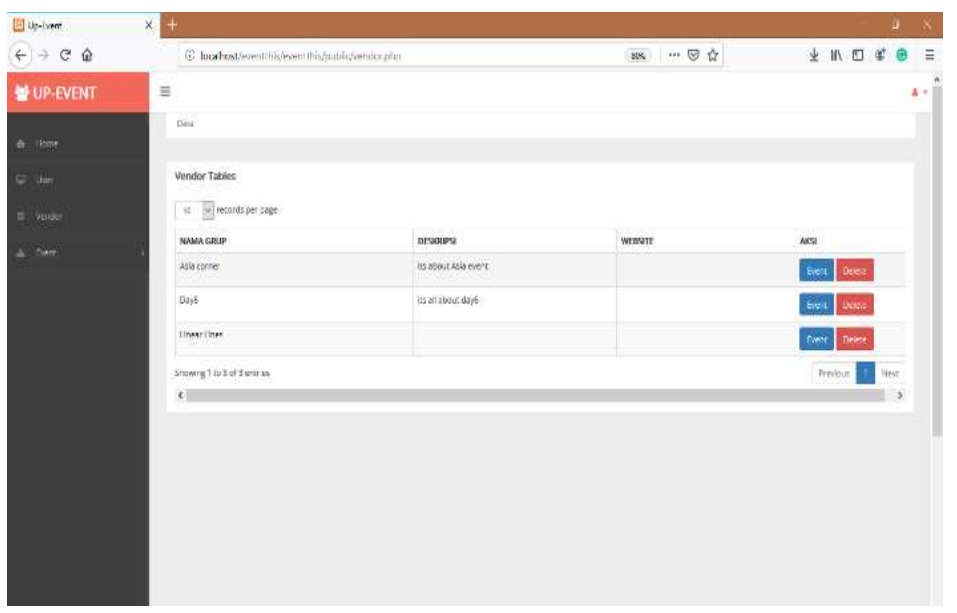

Gambar 10 Antarmuka Halaman Vendor

c. Antarmuka halaman event

Pada tabel event berisi tentang acara yang telah dibuat oleh grup event organizer. Berikut antarmuka halaman event

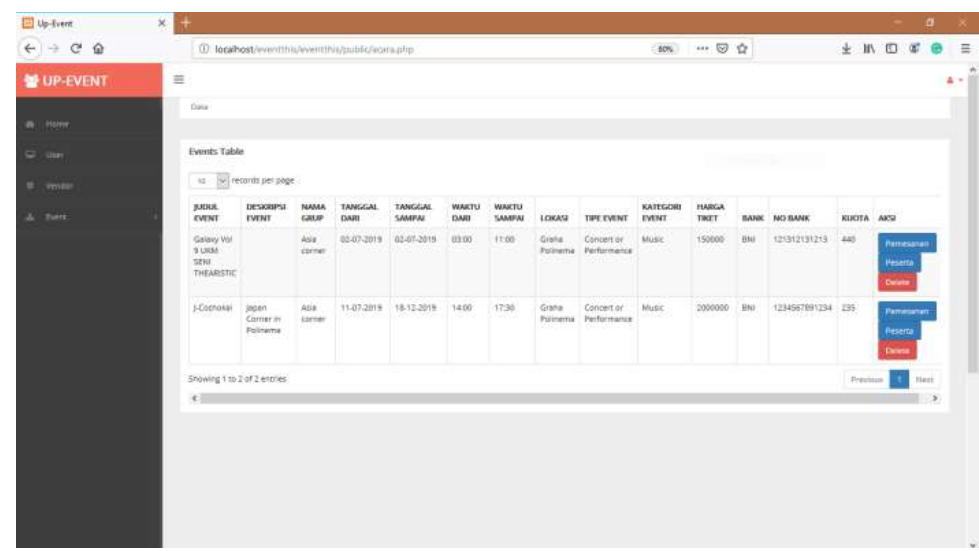

Gambar 11 Antarmuka Halaman Event

d. Antarmuka Menu Home

Antarmuka menu home ini berisi tentang daftar event yang akan berlangsung. Terdapat pula fitur pencarian untuk memudahkan user mencari event yang hendak diikutinya. Proses pencarian dilakukan dengan memasukkan kata kunci, dapat berupa nama event ataupun event organizer pengelolanya. Berikut merupakan antarmuka menu home dan pencarian event. 


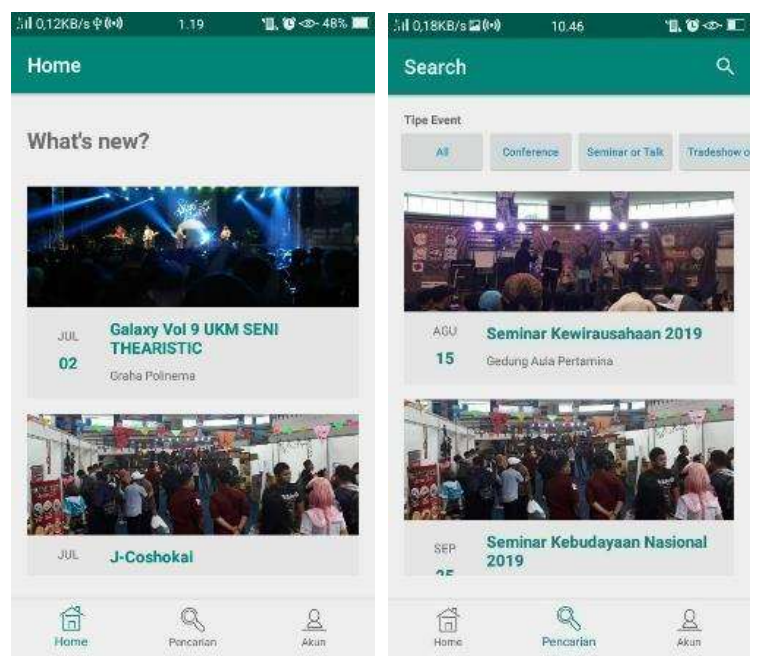

Gambar 11 Antarmuka Menu Home

e. Antarmuka EventOrganizer yang dikelola

Berikut merupakan antarmuka eventorganizer yang dikelola. Pada antarmuka ini user dapat melihat grup eventorganizerapa saja yang dia kelola. Pada halaman ini user juga dapat membuat eventorganizer-nya sendiri.

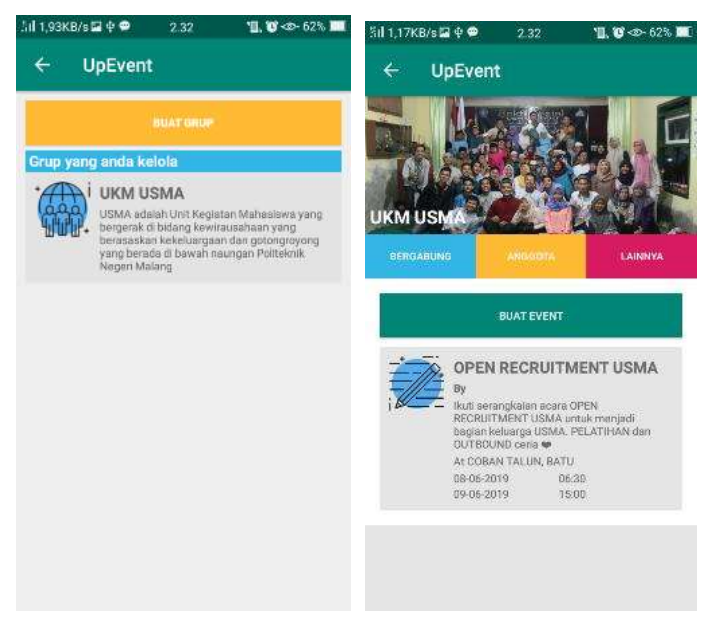

Gambar 12 Antarmuka Daftar EventOrganizer

Antarmuka ini merupakan antarmuka grup eventorganizer, pada halaman ini terdapat daftar event-event dari grup event organizer dan juga dilengkapi fitur-fitur untuk mengelola grup event organizer.

\section{f. Antarmuka Halaman Event}

Antarmuka ini merupakan antarmuka detail event, pada halaman ini event organizer dapat mengelola event,seperti mengubah detail event, mengkonfirmasi pembayaran, scanQR Code tiket dan lainnya. Berikut merupakan antarmuka halaman event. 


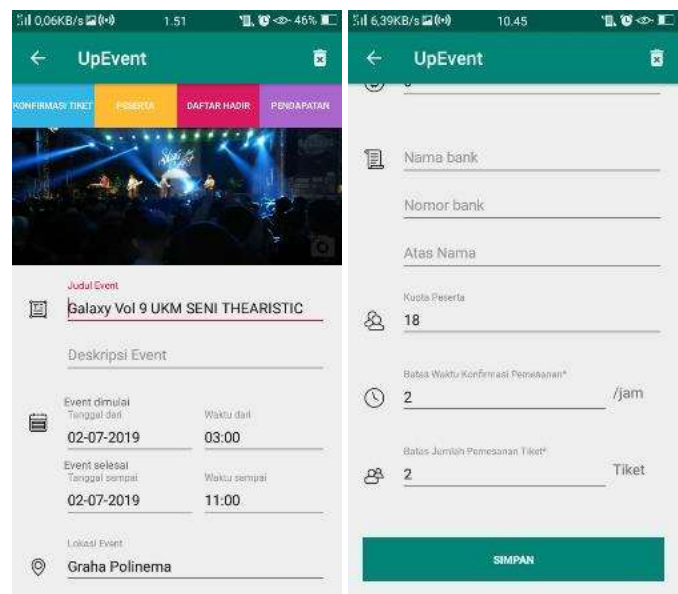

Gambar 13 Antarmuka Halaman Event

\section{g. Antarmuka Daftar Peserta}

Antarmuka ini berisi daftar peserta ini merupakan daftar dari peserta yang sudah memiliki tiket masuk. Tiket masuk berupa kode unik berdasarkan transaksi yang berbentuk QRCode. Kemudian terdapat pula antarmuka daftar peserta pada masing-masing event. Antarmuka ini berisi daftar peserta yang hadir saat event berlangsung. Di halaman ini terdapat fitur ScanQR Code dan presentase kehadiran peserta. Berikut merupakan daftar hadir peserta event.

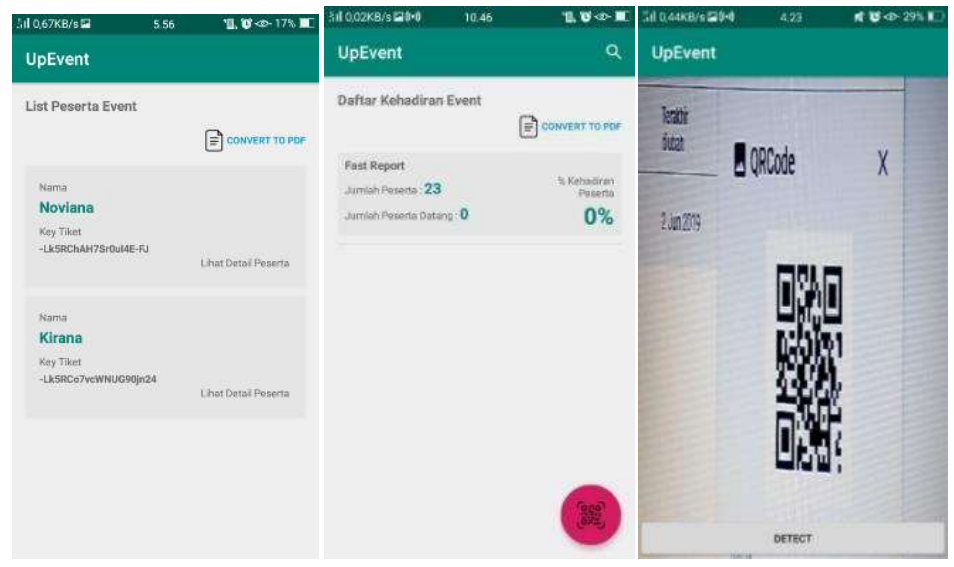

Gambar 14 Halaman Daftar Peserta Event

h. Antarmuka Daftar Konfirmasi Pembayaran Tiket

Halaman ini digunakan pengguna untuk melihat daftar konfirmasi pembayaran yang diajukan oleh peserta yang ingin mengikuti event. Pembayaran dilakukan dengan menggunkan rekening bersama milik vendor. Setelah melakukan pembayaran, user dapat melita riwayat pemesanan tiket. Berikut merupakan antarmuka daftar konfirmasi pembayaran tiket dan riwayat pemesanan. 


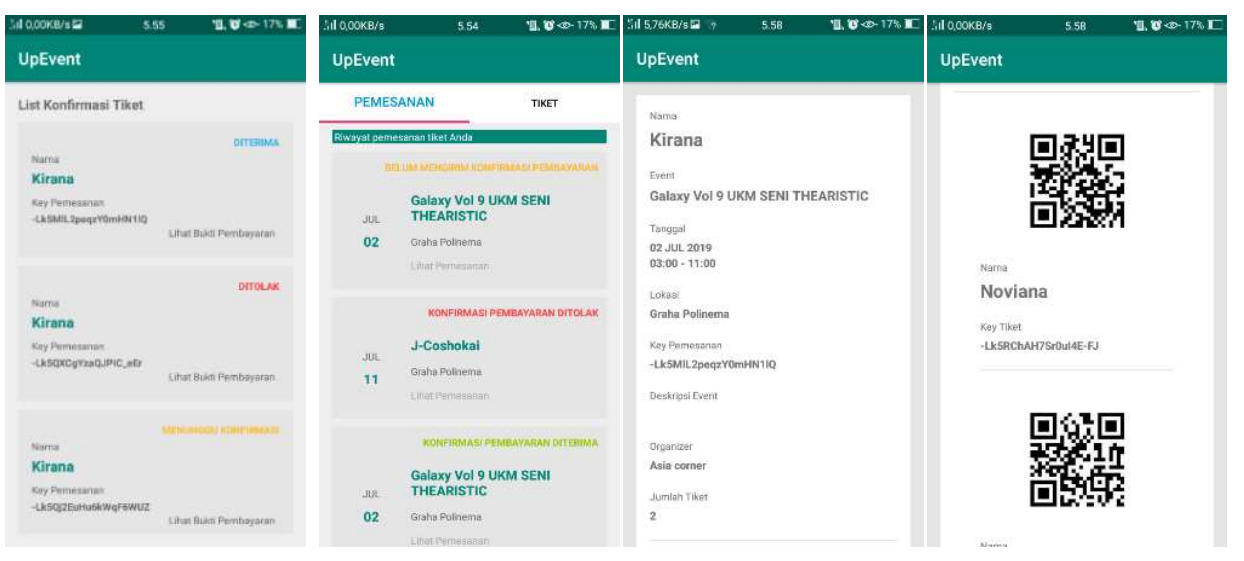

Gambar 15 Halaman Konfirmasi Tiket

\subsection{Pengujian}

Pengujian system dilakukan dengan menggunakan metode black box. Pengujian tipe ini lazim digunakan untuk melihat unjuk kerja dari sebuah system. Pengujian dilakukan dengan cara mencoba semua utilitas konten yang ada dalam system yang dibangun. Apabila ada beberapa perubahan berupa perbaikan system, dilakukan semata-mata untuk memperbaiki kualita dari system tersebut. Dari pengujian yang dilakukan didapatkan beberapa hasil yang tertera pada Tabel 1. Data yang tersaji dalam tabel 1 tersebut menggambarkan bahwa fungsi dari konten-konten yang tersedia dalam aplikasi sudah dapat berjalan dengan baik. Beberapa konten utama seperti, register, manajemen event, pembayaran dan cek user (presensi kedatangan event) juga berjalan sesuai dengan desain perancangan yang dibuat [9]. Konten unggulan dari aplikasi ini yakni manajemen event dalam multi vendor juga dapat berjalan dengan baik.

Tabel 1. Pengujian Black Box

\begin{tabular}{cccc}
\hline \hline Sample Data & Expected Result & Result & Conclusion \\
\hline Register & TRUE & TRUE & TRUE \\
Login & TRUE & TRUE & TRUE \\
Cari Event & TRUE & TRUE & TRUE \\
Home & TRUE & TRUE & TRUE \\
Manajemen akun & TRUE & TRUE & TRUE \\
Manajemen Even & TRUE & TRUE & TRUE \\
Ticketing & TRUE & TRUE & TRUE \\
Pembayaran & TRUE & TRUE & TRUE \\
Kalkulasi Pembayaran & TRUE & FALSE & FALSE \\
Record Bayar & TRUE & TRUE & TRUE \\
Record Peserta & TRUE & TRUE & TRUE \\
Cek Kehadiran Peserta & TRUE & TRUE & TRUE \\
Record Ticketing & TRUE & TRUE & TRUE
\end{tabular}

Hal ini ditunjukkan pada proses pendaftaran banyak vendor dan proses pemilihan event oleh user berdasarkan vendor juga berjalan dengan baik. Record pemesanan tiket, bukti kedatangan user serta bukti pembayaran tiket juga tersaji dengan baik pada system. Selanjutnya aplikasi dapat didistribusikan dan digunakan untuk tata kelola event multi vendor. Ujicoba dilakukan pada 20 user yang berlaku sebagai user / peserta, event organizer dan ademin. Pengujian aspek usability dilakukan dengan metode kuesioner. Analisis hasil kuesioner yang diperoleh ditunjukkan pada Tabel 2. 
Tabel 2. Analisis Hasil Kuesioner System Usability Scale (SUS).

\begin{tabular}{|c|c|c|c|c|c|c|c|c|c|c|c|}
\hline \multirow[b]{2}{*}{ Responden } & \multicolumn{10}{|c|}{ Item Pertanyaan } & \multirow[b]{2}{*}{ Skor SUS } \\
\hline & q1 & q2 & q3 & q4 & q5 & q6 & q7 & q8 & q9 & q10 & \\
\hline r1 & 4 & 2 & 5 & 2 & 4 & 2 & 4 & 1 & 4 & 2 & 80,0 \\
\hline r2 & 4 & 2 & 4 & 2 & 4 & 2 & 5 & 1 & 4 & 2 & 80,0 \\
\hline r3 & 4 & 2 & 4 & 3 & 4 & 3 & 4 & 2 & 4 & 2 & 70,0 \\
\hline r4 & 4 & 2 & 4 & 3 & 4 & 3 & 5 & 1 & 4 & 3 & 72,5 \\
\hline r5 & 4 & 2 & 4 & 1 & 4 & 2 & 4 & 2 & 3 & 2 & 75,0 \\
\hline r6 & 4 & 2 & 5 & 2 & 4 & 1 & 3 & 3 & 4 & 3 & 70,0 \\
\hline r7 & 4 & 2 & 4 & 2 & 4 & 4 & 4 & 2 & 4 & 2 & 70,0 \\
\hline r8 & 4 & 2 & 4 & 3 & 4 & 1 & 4 & 2 & 4 & 2 & 75,0 \\
\hline r9 & 4 & 2 & 4 & 3 & 4 & 1 & 4 & 2 & 4 & 2 & 75,0 \\
\hline r10 & 4 & 1 & 4 & 1 & 4 & 3 & 4 & 2 & 4 & 1 & 80,0 \\
\hline r11 & 3 & 3 & 4 & 2 & 5 & 1 & 3 & 2 & 4 & 2 & 72,5 \\
\hline r12 & 3 & 3 & 4 & 1 & 4 & 1 & 4 & 3 & 4 & 3 & 70,0 \\
\hline r13 & 3 & 2 & 5 & 2 & 3 & 3 & 5 & 2 & 3 & 3 & 67,5 \\
\hline r14 & 4 & 1 & 4 & 1 & 3 & 2 & 4 & 1 & 4 & 2 & 72,5 \\
\hline r15 & 4 & 3 & 4 & 3 & 4 & 3 & 4 & 2 & 4 & 2 & 70,0 \\
\hline $\mathrm{r} 16$ & 3 & 3 & 5 & 1 & 3 & 2 & 3 & 1 & 3 & 1 & 85,0 \\
\hline r17 & 4 & 2 & 4 & 2 & 4 & 3 & 4 & 3 & 3 & 1 & 70,0 \\
\hline r18 & 4 & 2 & 5 & 2 & 4 & 2 & 5 & 1 & 4 & 1 & 85,0 \\
\hline r19 & 3 & 2 & 5 & 3 & 4 & 2 & 4 & 2 & 4 & 3 & 70,0 \\
\hline r20 & 3 & 3 & 3 & 1 & 4 & 3 & 3 & 4 & 3 & 2 & 65,0 \\
\hline \multicolumn{11}{|c|}{ Jumlah } & 1475,0 \\
\hline \multicolumn{11}{|c|}{ Rata-rata skor SUS } & 73,75 \\
\hline
\end{tabular}

Berdasarkan perhitungan hasil kuesioner diperoleh rata - rata skor SUS 73,75. Rata - rata skor SUS kemudian dibandingkan dengan Tabel 10 mengenai rentang skor SUS[10]. Rata - rata skor 80 SUS 73,75 termasuk pada kategori acceptable, hal ini menunjukkan bahwa aplikasi yang dikembangkan dapat diterima oleh pengguna akhir dengan baik ditinjau dari aspek usability. Selain itu, hasil nilai Cronbach Alpha yang diperoleh dari perhitungan SPSS sebesar 0.821. Berdasarkan intepretasi nilai konsistensi alpha, nilai alpha sebesar 0.821 masuk pada kategori "good".

\section{SIMPULAN}

Berdasarkan pembahasan yang diperoleh maka dapat ditarik kesimpulan sebagai berikut:

1. Terbentuknya sistem Up-Event yang memudahkan event organizer dalam memanajemen event dan memudahkan user dalam melakukan transaksi tiket.

2. Manajemen event yang dilakukan difokuskan pada proses transakasi pembelian tiket oleh user, check kedatangan, dan upload informasi event.

3. Pengguna dapat dengan mudah memesan tiket dengan bukti transaksi berupa file digital dan event organizer dapat melakukan check kedatangan masing-masing user pada saat event berlangsung, hal ini bertujuan untuk menghitung jumlah user yang hadir.

4. Seluruh fitur dalam aplikasi dapat berjalan dengan baik, hal ini ditunjukkan pada analisis unjuk kerja menggunakan black Box. Data yang didapat sebagian besar fitur berjalan sesuai dengan harapan. 
5. Feed back dari pengguna aplikasi juga menunjukkan hasil yang positif. Hal ini ditunjukkan dari Analisis Hasil Kuesioner System Usability Scale (SUS) yang menunjukkan kategori "good" dengan skor akhir 73,75 .

\section{DAFTAR PUSTAKA}

[1] P. D. D. Akn, K. Demak, P. N. Jakarta, P. Studi, and J. Pariwisata, "Program Studi Jasa Pariwisata Manajemen Event," Manaj. Event, 2016.

[2] M. Program, S. Magister, and I. Komunikasi, "Social Strategy Pada Media Sosial Untuk Promosi Pariwisata Daerah Istimewa Yogyakarta," vol. 4, no. 2, pp. 195-201, 2015, doi: 10.14710/interaksi,4,2,195-201.

[3] A. Sarkar, “Application of Fuzzy Logic in Transport Planning," Int. J. Soft Comput., vol. 3, no. 2, pp. 1-21, 2012, doi: 10.5121/ijsc.2012.3201.

[4] A. Suryadi and S. I. Nurmawati, "Sistem Informasi Penjualan Kerajinan Berbasis Web Menggunakan Model V-Model (Studi Kasus Karang Taruna Pelitamas Banjarnegara), ' J. IJCIT (Indonesian J. Comput. Inf. Technol., vol. 3, no. 2, pp. 269-276, 2018.

[5] A. Anharudin, "Analisa dan Perancangan Sistem Informasi Sales Order (SO) Berbasis Web dengan PHP SQL (Studi Kasus : PT. Abc Steel ),” JSiI (Jurnal Sist. Informasi), vol. 4, pp. 2-5, 2018, doi: 10.30656/jsii.v4i0.366.

[6] R. N. W, S. Romlah, and U. D. Rosiani, "Sistem Informasi Data Keuangan Laporan Akuntabilitas Kinerja Instansi Pemerintah (LAKIP) Politeknik Negeri Malang,” J. Inform. Polinema, pp. 41-47, 2015.

[7] L. Dorothy, K. I. Satoto, and O. D. Nurhayati, "Perancangan dan Implementasi Sistem Informasi Perpustakaan di Program Studi Teknik Lingkungan Fakultas Teknik Undip,” J. Teknol. dan Sist. Komput., vol. 2, no. 4, pp. 209-222, 2014, doi: 10.14710/JTSISKOM.2.4.2014.209-222.

[8] V. Borimnejad and R. Eshraghi Samani, "Modeling consumer's behavior for packed vegetable in 'Mayadin management organization of Tehran' using artificial neural network," Cogent Bus. Manag., vol. 3, no. 1, pp. 1-14, 2016, doi: 10.1080/23311975.2016.1208898.

[9] B. A. Bernstein, J. C. M. Geurtz, and V. J. Koeman, "Evaluating the effectiveness of multi-agent organisational paradigms in a real-time strategy environment," Proc. Int. Jt. Conf. Auton. Agents Multiagent Syst. AAMAS, vol. 2, pp. 754-762, 2019.

[10] C. Mühl, O. Sheil, L. Jarutytè, and P. E. G. Bestelmeyer, “The Bangor Voice Matching Test: A standardized test for the assessment of voice perception ability," Behav. Res. Methods, vol. 50, no. 6, pp. 2184-2192, 2018, doi: 10.3758/s13428-017-0985-4. 